\title{
Falsely elevated serum follicle-stimulating hormone levels in the context of heterophilic interference and response of these patients to IVF/ICSI: case reports
}

\author{
Shipra Nigam*, Kundavi Shankar, Thankam Rama Varma
}

Institute of Reproductive Medicine \& Women's Health, Madras Medical Mission Hospital, Chennai, India

Received: 08 February 2016

Accepted: 05 March 2016

*Correspondence:

Dr. Shipra Nigam,

E-mail: docshipranigam@ rediffmail.com

Copyright: () the author(s), publisher and licensee Medip Academy. This is an open-access article distributed under the terms of the Creative Commons Attribution Non-Commercial License, which permits unrestricted non-commercial use, distribution, and reproduction in any medium, provided the original work is properly cited.

\begin{abstract}
Heterophilic antibodies can introduce errors in commonly used immunoassays, including those used for the peptide hormones FSH and LH. Heterophilic antibodies are human antibodies that can bind animal antibodies. They can cause problems in immune assays, particularly immunometric assays where they can form a bridge between capture and detection antibodies leading to false increase in measured concentrations. Serum FSH levels, as detected by immunoassay kits, have been recognized as a useful diagnostic and prognostic tool in reproductive medicine because they are a reliable marker of the ovarian follicular status and a predictor of the ovarian response to controlled ovarian hyperstimulation. Hence, the possibility of falsely elevated FSH levels due to heterophilic interference must be taken into account. Here, we report six cases positive for heterophilic antibodies whose serum samples had initial FSH values more than $10 \mathrm{IU} / \mathrm{ml}$. They were subjected to repeat analysis as their antral follicle count and AMH were within normal limits. The repeat values were high and then serum samples were studied in dilution. Blood samples for FSH were also sent for interlab check. The samples showed significant lowering of values in both dilution and interlab checks and then subjected to the heterophilic antibody detection test. The detection of heterophilic antibodies appears to be Kit specific as interlab check give significantly different values. Out of the six patients, three patients underwent IVF/ICSI treatment with two of the three showing normal response. Interference with heterophilic antibodies must be thought of in case of discrepancy between the clinical context and biological markers obtained with immunoassays.
\end{abstract}

Keywords: Heterophilic antibody, FSH, LH, Heterophile Blocking Reagent (HBR)

\section{INTRODUCTION}

Immunometric assays are inherently vulnerable to interference from heterophilic antibodies, endogenous antibodies that bind assay antibodies. The consequences of such interference can be devastating. ${ }^{1}$ Heterophilic antibodies are common, naturally occurring antibodies with low affinities. These antibodies initiate weak interactions between antigens and antibodies, and may function to regulate the immune system. Medical researchers have proposed that heterophilic antibodies bind and remove foreign antigens from the intestinal tract and help maintain self-tolerance. ${ }^{2}$ These antibodies react with many antigens, including a wide variety of chemical structures, self-antigens, and the variable region of other antibodies (anti-idiotypic antibodies). Heterophilic antibodies are inherently produced from B cells prior to antigen exposure and result from random combinations of the genes of the heavy and light chain variable regions. Heterophilic antibodies are not the same as specific human anti-animal antibodies, which are produced when animal antibodies are injected into a patient for treatment or diagnostic purposes. ${ }^{3,4}$ Heterophilic interference in immunoassay caused by endogenous immunoglobulin can drastically affect patient management.

\section{CASE REPORT}

In our centre IRM, MMM hospital, we found six cases positive for heterophilic antibodies where patients were 
evaluated for infertility and where initial Follicle Stimulating Hormone (FSH) value was more than 10 $\mathrm{IU} / \mathrm{mL}$ despite of normal Antral Follicle Count (AFC) and Anti Mullerian Hormone (AMH) values. We communicated with the laboratory and all cases were subjected to repeat analysis. Repeat values were high and then the same samples were studied in dilution. Samples were also sent for an interlab check. The samples showed significant lowering of values in both dilution and interlab check (Table 1). Samples were then subjected to the heterophilic antibody detection test which was positive for the same.

Out of six cases, three patients had undergone controlled ovarian stimulation. Only one patient had poor response to stimulation despite of good antral follicle count and normal AMH. Rest two patient had normal response (Table 2).

Table 1: Details of six cases with their AMH, AFC Levels and their FSH Values before and after dilution.

\begin{tabular}{|llllllll|}
\hline Case & $\begin{array}{l}\text { AMH } \\
(\mathrm{ng} / \mathrm{mL})\end{array}$ & AFC & $\begin{array}{l}\text { AGE } \\
\text { (in years) }\end{array}$ & $\begin{array}{l}\text { FSH value } \\
(\mathrm{IU} / \mathrm{mL})\end{array}$ & $\begin{array}{l}\text { FSH Value on } \\
\text { dilution } \\
(\text { IU/mL) }\end{array}$ & $\begin{array}{l}\text { Expected } \\
\text { FSH Value } \\
\text { after dilution }\end{array}$ & $\begin{array}{l}\text { Final FSH } \\
\text { Value } \\
\text { (IU/mL) }\end{array}$ \\
\hline 1 & 3.99 & $10 / 10$ & $25 \mathrm{yr}$ & 23.7 & 5.11 & 14.5 & 9.91 \\
\hline 2 & 3.8 & $10 / 8$ & $29 \mathrm{yr}$ & 15.1 & 4.46 & 6.8 & 8.08 \\
\hline 3 & 6.8 & $7 / 3$ & $32 \mathrm{y}$ & 23.3 & 8.52 & 10.5 & 16.9 \\
\hline 4 & 6.11 & $7 / 12$ & $29 \mathrm{y}$ & 12.7 & 6.17 & 8.14 & 6.79 \\
\hline 5 & 2.4 & $4 / 8$ & $30 \mathrm{yr}$ & 11 & 5.64 & 7.45 & 6.7 \\
\hline 6 & 1.3 & $6 / 2$ & $33 \mathrm{yr}$ & 19.8 & 9.29 & 9.84 & 7.58 \\
\hline
\end{tabular}

Table 2: Details of three patients who underwent controlled ovarian stimulation.

\begin{tabular}{|llllllllll|}
\hline Case & $\begin{array}{l}\text { AGE } \\
\text { (in } \\
\text { years) }\end{array}$ & $\begin{array}{l}\text { AMH } \\
(\mathrm{ng} / \mathrm{mL})\end{array}$ & AFC & $\begin{array}{l}\text { FSH } \\
\text { value } \\
(\text { IU/mL) }\end{array}$ & $\begin{array}{l}\text { FSH } \\
\text { value on } \\
\text { dilution }\end{array}$ & $\begin{array}{l}\text { Expected } \\
\text { FSH value } \\
(\text { IU/mL) }\end{array}$ & $\begin{array}{l}\text { Final } \\
\text { FSH } \\
\text { value } \\
\text { (IU/mL) }\end{array}$ & $\begin{array}{l}\text { Gonadotropin } \\
\text { used } \\
\text { (Total dose in }\end{array}$ & $\begin{array}{l}\text { Eggs } \\
\text { Collected }\end{array}$ \\
\hline 1 & $25 \mathrm{yr}$ & 3.99 & $10 / 10$ & 23.7 & 5.11 & 14.5 & 9.91 & 2550 & 5 \\
\hline 2 & $29 \mathrm{yr}$ & 3.8 & $10 / 8$ & 15.1 & 4.46 & 6.8 & 8.08 & 2225 & 15 \\
\hline 4 & $29 \mathrm{yr}$ & 6.11 & $7 / 12$ & 12.7 & 6.17 & 8.14 & 6.79 & 1687.5 & 8 \\
\hline
\end{tabular}

\section{DISCUSSION}

Since there was an obvious mismatch in our patients between clinical findings (AFC, Age), laboratory results for $\mathrm{AMH}$ and the serum FSH values, we discussed the same with our laboratory. The samples were reassessed for FSH values in dilution and FSH values were found to be normal. This falsely high FSH values was due to interference by heterophile antibodies. Two cases of heterophilic antibodies interfering with FSH estimation have been reported by Webster et al. ${ }^{5}$ We further observed the IVF/ICSI outcome in these patients with positive heterophile antibody. Out of six, three patients had undergone IVF/ICSI and two out of three had normal response but one patient had poor response. At present in view dearth of literature it is not possible for us to comment whether this poor response was due to heterophile antibody or due to some other cause.

Clinicians need to be aware of the challenges caused by heterophilic antibodies. It is fundamental to know the existence of interference with heterophilic antibodies in case of discrepancy between the clinical context and biological markers obtained with immunoassays. Prompt communication between clinicians and the laboratory is essential so that a second alternate test may be used. Therefore, it is necessary to remain critical in the presence of a discordant lab results to identify falsepositive results caused by heterophilic antibodies to avoid any profound impact on the clinical management of patients.

Funding: No funding sources

Conflict of interest: None declared

Ethical approval: Not required

\section{REFERENCES}

1. Bolstad N, Warren DJ, Nustad K. Heterophilic antibody interference in immunometric assay. Best Pract Res Clin Endocrinol Metab Oct. 2013;27(5):647-61. 
2. Levinson SS, Miller JJ. Towards a better understanding of heterophile (and the like) antibody interference with modern immunoassays. Clin Chim Acta. 2002;325(1-2):1-15.

3. Warren DJ, Bjerner J, Paus E, Bormer OP, Nustad K. Use of an in vivo biotinylated single chain antibody as capture reagent in an immunometric assay to decrease the incidence of interference from heterophilic antibodies. Clin Chem. 2005;51(5):8308.
4. Bjerner J, Olsen KH, Bormer OP, Nustad K. Human heterophilic antibodies display specificity for murine IgG subclasses. Clin Biochem. 2005;38(5):465-72.

5. Webster R, Fahie-Wilson M, Barker P, Chatterjee VK, Halsall DJ. Immunoglobulin interference in serum follicle-stimulating hormone assays: autoimmune and heterophilic antibody interference. Ann Clin Biochem. 2010;47(Pt4):386-9.

Cite this article as: Nigam S, Shankar K, Varma TR. Falsely elevated serum follicle-stimulating hormone levels in the context of heterophilic interference and response of these patients to IVF/ICSI: case reports. Int J Reprod Contracept Obstet Gynecol 2016;5:1251-3. 